30.07 .03

\title{
European Institutions and Identity Change: What Have We Learned?
}

by

Thomas Risse

prepared for Richard Herrmann, Marilynn Brewer, and Thomas Risse (eds.), Identities in Europe and the Institutions of the European Union (Lanham MD: Rowman \& Littlefield, forthcoming)

Author's Address:

Department of Political and Social Sciences

Center for Transatlantic Foreign and Security Policy

Freie Universität Berlin

Ihnestr. 22

14195 Berlin

Germany

Phone: ++49-(0)30-838.55527

Fax: ++49-(0)30-838.54160

Email: risse@zedat.fu-berlin.de

Website: http://fu-berlin.de/atasp 


\section{Introduction ${ }^{1}$}

This book has both theoretical and empirical purposes. Theoretically, we strive to understand how new (international) institutions affect or otherwise change people's social identities. How do political institutions shape people's beliefs about who they are and to which communities they belong? What are the causal pathways by which institutions affect social identities and by which identities and institutions co-evolve? Empirically, we focus on the European experience, in particular the way in which more than forty years of European integration have affected people's sense of belonging. Is there an emerging European identity, and if so, does it replace, co-exist with, or otherwise interact with individual's multiple identities? And what is the substantive content of this European identity? Is there a difference between elite-level identification processes with Europe and the Europeanness of "ordinary" people?

To answer these questions, we have embarked upon a multi-disciplinary and -methodological approach. The authors in this book are political scientists, sociologists, social psychologists, linguists, and anthropologists using such diverse research tools as quantitative survey data, laboratory experiments, in-depth interviews, discourse analysis, and historical interpretation. Our hope was that a multi-dimensional approach would give us additional analytical leverage in tackling such an elusive concept as "European identity."

In the following, I try to summarize some of our findings, to highlight agreements as well as differences among the authors, and to suggest avenues for future research. I concentrate on a discussion of the empirical findings of the book. While the introduction by Brewer and Herrmann focussed primarily on theoretical questions involved in studying collective identities, I emphasize what we learned on the empirical subject of European identity. Therefore, this chapter focusses on the insights from a multidisciplinary approach on describing European identity as the 'dependent variable.' How do European and other identities of individuals and social groups go together (2.)? What do we know about the substance and content of European identity (3.)? How can we explain the

\footnotetext{
${ }^{1}$ I thank Tanja Börzel, Marilynn Brewer, Richard Herrmann, and an anonymous reviewer for critical comments on the draft and the participants in the joint project of the Robert Schuman Centre and the Mershon Center for clarifying my views on the subject. Many insights developed in the following also stem from discussions of the 1999-2001 European Forum "Between Europe and the Nation-State" at the European University Institute's Robert Schuman Centre of Advanced Studies. Finally, I thank the students of the postgraduate program on European studies in Berlin for their critical comments.
} 
large gap between elite identification with Europe and the feelings of ordinary citizens who seem to be more alienated from Europe (4.)?

While the chapters in this book provide excellent descriptions of what we seem to know about the extent to which people identify with Europe, they are less concerned with explaining the evolution of European identity. Nevertheless, this book yields some insights on the reasons why we can see changes over time in identification with Europe (5.). I will also highlight methodological problems in studying the subject matter of European identity which seem to be apparent in this volume (6.). I conclude with the implications of our findings for the policy debates about the future of the European Union (7.). Why bother with studying identities? Do we need European identity to build a European polity?

\section{European and Other Identities: How Do They Go Together?}

It is no longer controversial among scholars and - increasingly - policy-makers that individuals hold multiple social identities. People can feel a sense of belonging to Europe, their nation-state, their gender, etc. It is wrong to conceptualize European identity in zero-sum terms, as if an increase in European identity necessarily decrease one's loyalty to national or other communities. Europe and the nation are both "imagined communities" (Anderson 1991) and people can feel as part of both communities without having to choose some primary identification. Analyses from survey data suggest and social psychological experiments confirm that many people who strongly identify with their nation-state, also feel a sense of belonging to Europe (Duchesne and Frognier 1995; Martinotti and Steffanizzi 1995; see chapters by Citrin/Sides and by Castano).

However, there are social contexts in which European and national identities might conflict. Two of Siapera's narratives concern situations in which journalists feel that they have to take sides in a confrontation between "Europe" and the nation-state. According to one account, Europe has to be built against the nation-state and a European public opinion is supposed to overcome old-fashioned nationalism. The other account takes the opposite perspective and assumes that national identities cannot be superseded by the construction of Europe (Siapera's chapter). Laffan's account of "double hating" in the Committee of Permanent Representatives at the Council (COREPER) also suggests a sometimes conflictual relationship between European and national identities among officials working in Brussels. This conflict results from somewhat contradictory role identities of these offi- 
cials. On the one hand, they are supposed to work toward a common European goal and negotiate consensual outcomes with their fellow Europeans (see also Lewis 1998a, b, 2000). On the other hand, they are still national representatives and, therefore, supposed to defend their respective national interests.

Interestingly enough, zero-sum relationships and potential conflicts between European and national identities are represented in this book only in cases focussing on professionals working in Brussels. Journalists reporting from Brussels to their national media markets and COREPER officials have in common that Europe and their respective nation-states are highly salient and "real" entities for them. Both are very entitative, to use the term from social psychology (Castano's chapter). Journalists and national permanent representatives have to constantly negotiate between their commitment to Europe and their commitment to their nation-state. No wonder that these two groups perceive Europe and the nation often in conflict with each other. It seems to be the social context of their professional environment that leads them to sometimes conceptualize the two identities in conflictual terms.

However, the other chapters of this book show little evidence of a zero-sum relationship between European and other identities. This finding is trivial for scholars studying collective identities, but it nevertheless has important implications for the political debates about Europe and the nation-state. Take the contemporary debate about the future of the European Union and about a European constitution. Many people still hold that Europe lacks a demos, one indicator being the lack of strong identification with Europe in mass public opinion (e.g. Kielmansegg 1996). Yet, as Citrin and Sides demonstrate, "country first, but Europe, too" is the dominant outlook in most EU countries and people do not perceive this as contradictory (for similar findings see Marks and Hooghe 2003). Moreover and more important, the real cleavage in mass opinion is between those who only identify with their nation, on the one hand, and those perceiving themselves as attached to both their nation and Europe, on the other hand. Citrin and Sides show that the individual willingness to support further European integration increases quite dramatically from the former to the latter group. Marks and Hooghe add that exclusive identification with the nation-state is more powerful in explaining opposition against European integration than calculations about economic costs and benefits (Marks and Hooghe 2003). They also show that the effect of exclusive identification with one nation-state varies widely across countries. "Nationalist" Portuguese are far less inclined to oppose European integration than, say, "nationalist" British. 
Generally speaking, therefore, willingness to grant the EU authority requires some identification with Europe, but not one that actually prioritizes Europe over the nation. In other words, the European polity does not require a "demos" that replaces a national with a European identity, but one in which national and European identities co-exist and complement each other. This is a significant empirical finding which speaks directly to the current debate on the future of the union.

Our findings show much more than the rather simple insight that European and national identities can go together. The chapters suggest quite a bit on how multiple identities go together and how they relate to each other. The introduction of this book suggested three ways in which we can think of multiple identities. First, identities can be nested, conceived of as concentric circles or Russian Matruska dolls, one inside the next. My identity as Rhinelander is nested in my German identity which is again nested in my Europeanness. Second, identities can be cross-cutting. In this configuration, some, but not all, members of one identity group are also members of another identity group. I can feel a strong gender identity and a sense of belonging to Europe, but not all members of my gender group also identify with Europe. Third, identities can be separate. For example, I could be the only professor in a sports club as a result of which my identification with my professional colleagues would be kept separate from my loyalty to the soccer club associates. There would be no overlap in group memberships.

There is a lot of evidence presented in this book that we can think of the relationship between European and other identities as nested and/or cross-cutting, while there are only few instances of separate European and other identities. As to nestedness, we find the "Russian Matruska doll" model of European and other identities on both the level of elites and of mass public opinion. This model suggests some hierarchy between people's sense of belonging and loyalties. European and other identities pertaining to territorially defined entities can be nested into each other so that "Europe" forms the outer boundary, while one's region or nation-state constitute the core. The survey data mentioned above that mass publics in most countries hold national and regional identities as their primary sense of belonging, while Europe runs a distinct second, are consistent with such a concept of how multiple identities relate (cf. chapters by Bruter and Citrin/Sides). Laffan and Wodak reports about Commission officials also suggest a nestedness of European identity, but here "Europe" forms the core, while national identification recedes into the background. Social context and entitativity (Castano's chapter) would explain the difference between the social identities of Commission officials and those of citizens in most EU member states. For the latter, Europe and the EU are distant realities at best and probably less reified than their imagined national communities. Meinhof's 
in-depth interviews with people in border regions suggest that Europe is indeed far away from people's daily lives. They would only refer to Europe when directly asked by the interviewer. Hence the ordering whereby national identities form the core and European identity the outer boundary of the Russian doll. For Commission officials, the social context works the other way round and pushes toward strong identification with Europe. Finally, the "Russian doll" idea is consistent with the data reported by Mummendey/Waldzus according to which national identities form a sub-group within a super-ordinate group, Europe in this case.

But we also see examples of cross-cutting identities. The chapters by Laffan and Wodak seem to suggest that Members of the European Parliament (MEPs) hold such overlapping identities of feeling a sense of belonging to Europe and to their party groups. The same holds true for the journalists in Brussels (see Siapera's chapter). Their professional identities cut across their identification with Europe. Siapera shows that distinct role identities of journalists as investigators, chroniclers, or therapeutic analysts go together with distinct perspectives on the construction of Europe (anti-national, national, post-national).

Unfortunately, most mass opinion survey instruments as well as the social psychological experiments reported in this volume do not evaluate identification with Europe as cross-cutting with other social identities. The implicit model of multiple identities behind these instruments is the Russian Matruska doll concept. Yet, we could even conceive of the relationship between European and national identities as cross-cutting. Some, but not all people who strongly identify with their nationstate also identify with Europe, as the Eurobarometer data suggest (chapter by Citrin/Sides). Moreover, the two groups - "nation only" and "nation and Europe" - hold rather different political attitudes across a wide range of issues. In particular, people identifying with their nation and with Europe are less nationalist, less xenophobic, and hold more cosmopolitan values in general (but see the findings by Mummendey/Waldzus on in-group projection discussed below). Their ideological convictions place them more to the left than their nationalist counterparts. Ideology in general represents another identity marker that cuts across European identity.

There is a fourth way of conceptualizing the relationship between European and other identities which people might hold. We could call it a "marble cake" model of multiple identities. Accordingly, the various components of an individual's identity cannot be neatly separated on different levels as both concepts of nestedness and of cross-cutting identities imply. What if identity components influence each other, mesh and blend into each other? What if my self-understanding as Ger- 
man inherently contains aspects of Europeanness? Can we really separate out a Catalan from a European identity? As another example, take the major European party families. From the 1950s on, Christian Democratic parties in Continental Europe were at the forefront of European integration. Europeanness has always been a constitutive component of post-World War II Christian Democratic ideology originating from the inter-war period. The same holds true for modern Social Democrats in Europe. It is interesting to note that the turn toward accepting capitalism and the social market economy which the German Social Democrats experienced in the late 1950s, the French Socialists in the early 1980s, and British Labor in the 1990s, went hand in hand with a stronger identification with European integration in each of these cases. Today, Europeanness forms a constitutive part of modern Social Democratic ideology (for details see Marcussen et al. 1999; Risse 2001).

The chapters in this volume do not systematically explore such a "marble cake" concept of European and other identities. Yet, most of the evidence is actually consistent with it, starting with the "nation first, Europe second" identification found in the Eurobarometer data (chapter by Citrin/Sides). Theoretically speaking, Breakwell's Identity Process Theory probably comes closest to such an understanding how European and other identity components might go together. The identity change of European Social Democracy described above, for example, could be analyzed in terms of the assimilation/accomodation dynamics to which she refers in her chapter. Moreover, as Breakwell points out, being European is not the same as being a citizen of a EU member state. EU membership leads to an identity change which impacts upon the previous national identity. Since EU membership identity then interacts with rather different national identity constructions, the overall effect will not be homogenous leading to a generalized EU identity. Rather, Europe and the EU become enmeshed with given national identities leading to rather diverging identity outcomes.

A most important corollary of such a conceptualization concerns the content and substance of what it means to identify with Europe. Breakwell talks about the "emptiness" of Europe as a category which implies that different groups might fill it with very different contents. Indeed, a longitudinal study of political discourses about Europe among the major parties in France, Germany, and Great Britain revealed that the meaning of Europe varied considerably (Marcussen et al. 1999; Risse et al. 1999). For the German political elites, "Europe" and the European integration meant overcoming one's own nationalist and militarist past (Engelmann-Martin 2002). The French elites, in contrast, constructed Europe as the externalization of distinct French values of Republicanism, enlightenment and the mission civilisatrice. While French and German political elites managed to embed Europe 
into their understandings of national identity, the British elites constructed Europe in contrast to their understandings of the nation, particularly the English nation (Knopf 2002).

Finally, the ingroup projection model presented by Mummendey and Waldzus points to the dangers of a European identity which is fully integrated into one's own national sense of belonging. Not only does this imply that "Europe" means different things to different people. If people simply transfer their own national values onto the European stage and if they fill their understanding of Europe with meanings derived from their national models of political and social life, this might in the end decrease rather than increase tolerance among the European peoples.

Whether nested, cross-cutting, or enmeshed: The various ways in which we can think about multiple identities and their relationships with each other suggest important desiderata for future research. It has become conventional wisdom among scholars that individuals hold multiple social identities. One can feel a sense of belonging to Europe as well as to one's region and/or political party. It is far less clear what this actually means. Future research should, therefore, specify the different ways in which the multiplicity of identities can be conceptualized, derive competing propositions from these models, and test them empirically.

So far, I have used the terms "European identity" or "Europe" as if its content and substantive meanings were clear and well-defined. Breakwell's notion of emptiness of Europe as a social identity marker already challenges this view. She notes that "Europe" and the "EU" connote different things for different people (see also Bruter's chapter). But what do our findings suggest on the substantive content of European identity in terms of both "who is us?" (composition of group identity) and "what is us?" (content of group identity; see the introduction)

\section{3. "Who is Us and What is Us"? The Composition and the Content of European Identity Europe's Emptiness as Identity Category}

The chapters in this book do not present a uniform picture of what it means in substantive terms to be European. Breakwell points to the possibility that the EU and Europe are poorly defined as super-ordinate categories and that, therefore, they may have various and rarely unchallenged social meanings. If European identity means quite different things to different people in terms of its ideological, territorial, political, or cultural and even religious connotations, it does not mean much if 
we find in survey data that people identify with "Europe." At least, we should not draw any major conclusions for the European polity. Moreover, the symbolic and mythological identity markers of Europe are rather weakly developed. Most people might by now recognize the European (EU) flag or European symbols on their passports, drivers' licenses, or automobile license plates (see also Bruter's chapter). There is also evidence that the single currency, the Euro, has already left a substantial mark in people's mind as a symbol of European integration. The introduction of Euro bills and coins in people's pockets has already begun to affect citizens' identification with the EU and Europe in general (see evidence in Risse 2003a). But how many people can identify the "ode of joy" as the European anthem?

Or take the events following the September 11, 2001, attacks on the United States. While policymakers all over Europe routinely referred to the need to build a strong European foreign and security policy in the fight against international terrorism, symbols of national foreign policies prevailed in the media representations. We watched British Prime Minister Tony Blair and German Chancellor Gerhard Schröder as well as their foreign ministers travelling around the globe, talking to Arab leaders, and making solemn statements at "ground zero" in New York. We rarely saw Mr. "European Foreign Policy" Solana at similar functions. We did not learn that every single statement by a European leader had been coordinated with the fellow Europeans through the framework of the European Common Foreign and Security Policy before it was being made. Things have further deteriorated over the intra-European conflict concerning the Iraq war. The common framework of European foreign policy was sidestepped and foreign policy became, once again, purely national affairs.

Breakwell's claim about the emptiness of Europe and the EU as identity categories is corroborated by Meinhof's findings from her in-depth interviews. There was no spontaneous mentioning of Europe or the EU by people in the border towns even though the significance of EU enlargement is quite obvious for them. When confronted with photographs containing European symbols, interviewees would still not refer to Europe. Only when asked direct questions concerning their attachment to Europe would people start talking about it. However, the statements were contradictory and inconsistent; respondents gave very different accounts of what Europe means for them (see Meinhof's chapter). These results differ substantially from the findings based on survey data which points to some methodological problems in measuring European identity. At least, we can probably infer that Europe was not a salient reality in the particular social context of Meinhof's interviews. 


\section{European or EU Identity?}

Apart from the problem that Europe might be an empty signifier for many people, we need to distinguish European and EU identity (cf. Breakwell's chapter). This is particularly important if we want to find out which effects, if at all, Europeanization and European integration has had on identity change. People might feel a sense of belonging to Europe in general, while feeling no attachment to the EU at all - and vice versa. Yet, as Laffan suggests, the EU as an active identity builder has successfully achieved identity hegemony in terms of increasingly defining what it means to belong to "Europe." First, EU membership has significant constitutive effects on European state identities. States in Europe are increasingly defined as EU members, non-members, or would-be members. Their status in Europe and to some degree also worldwide depends on these categories. There is no way that European states can ignore the EU, even such devoted non-members as Switzerland.

Second, the EU has achieved identity hegemony in the sense that "Europe" increasingly denotes the political and social space occupied by the EU. In the context of Eastern enlargement, Central Eastern European (CEE) states want to "return to Europe," as if they were currently outside the continent. When Italy prepared itself for entering the Euro zone, the main slogan was "entrare l'Europa" (entering Europe!) as if Italy - one of the six founding members of the European Community - had ever left it (Sbragia 2001). In these contexts, Europe is used synonymously with the EU. To the extent that people identify Europe with the EU, this would be a remarkable achievement of forty years of European integration. If Europe and the EU are used interchangeably, it means that the latter has successfully occupied the social space of what it means to be European. One could then not be a "real" European without being EU member. This point appears to contradict the notion of Europe as an empty identity category. At least, it would mean that the EU increasingly fills the meaning space of Europe with a specific content.

But what substantive content do people refer to when they identify with Europe and/or the EU? What attributes, symbols, and values describe the prototypical member of the European in-group (see the introduction by Brewer and Herrmann)? At this point, Bruter's distinction between civic and cultural components of European identity is quite helpful.

\section{Civic and/or Cultural Components of European Identity}

Bruter's chapter points out that it makes a difference whether Europe is defined in civic or cultural terms. 'Culture' in this understanding encompasses history, ethnicity, civilization, heritage, and 
other social similarities. 'Civic identity' instead is much more circumscribed and refers to identification of citizens with a particular political structure such as the EU or the political institutions of the nation-state (see also Eisenstadt and Giesen 1995). Bruter finds that people systematically distinguish between these two dimensions. His evidence is corroborated by a Europe-wide focus group study commissioned by the EU Commision's Governance Unit that also included nine accession candidates. This study shows that people by and large identify 'Europe' as a historical, political, and cultural space rather than a territorial entity (OPTEM 2001). In contrast, when Europe is introduced in mostly territorial terms, attachment rates drop dramatically, as a most recent Special Eurobarometer study shows (EOS Gallup Europe 2001). In this case, comparatively more people feel attached to the "world" than to Europe. In other words, it is Bruter's cultural identity that seems to form the substance of citizens' identification with Europe as a whole.

Bruter also points out that the distinction allows to differentiate between identification with the EU as a distinct civic and political entity, on the one hand, and a larger Europe as a cultural and historically defined social space, on the other. The distinction appears to resonate with quite a few chapters in this volume. As Laffan points out, European institutions - both the EU and the Council of Europe deliberately try to construct a postnational civic identity in the Habermasian sense (Habermas 1994, 1996; Dewandre and Lenoble 1994) emphasizing democracy, human rights, market economy, the welfare state, and cultural diversity. These values have become constitutive for the EU, since one cannot become a member without subscribing to them (from the Copenhagen criteria onwards). As the enlargement debates show, the self-description of the EU and the dominant discourses surrounding it have moved quite a long way toward building a polity and going beyond simple market integration (see also Laffan, O'Donnell, and Smith 2000). Wodak's data appear to corroborate the point, even though her findings suggest that European elite groups orient toward both civic and cultural components of European identity.

But does this civic understanding of European identity resonate with European citizens? If Bruter's findings were generalizable, the answer is yes. But Eurobarometer data, unfortunately, do not allow for distinguishing between cultural and civic understandings of European identity. Citrin and Sides present some evidence in their chapter which is at least consistent with Bruter's findings from his pilot studies with student groups. Education, income, and ideology all have a positive impact on levels of attachment to Europe. Moreover, attachment to Europe is strongly correlated with support for the EU and willingness to cede authority and sovereignty to EU institutions in various policy domains. Finally, the more people identify with Europe, the less xenophobic and the more positive 
toward Eastern enlargement they are. Hostility toward immigrants, in contrast, correlates strongly with exclusively national identifications. These findings support Laffan's rather optimistic statement that the EU has occupied the social identity space of 'Europe' and that the substance of 'Europe' contains more and more understandings consistent with a civic identity.

She also points out that the social construction of EU identity as put forward by EU institutions points to moral values such as democracy, human rights, and the like, as well as a commitment to the rule of law. A recent study of European discourses in the public sphere corroborates her argument. The debate about Jörg Haider and his populist party's entry into the Austrian government in 2000 as well as the EU reaction to it was framed in terms of the values which hold the EU together. 'Europe' was constructed as both a moral as well as a legal community and the EU "sanctions" against Austria were discussed in terms of whether they were consistent which European identity (for evidence see Van de Steeg et al. 2003; Risse 2003b).

Whether these data are generalizable remains to be seen. On the one hand, there is the evidence reported above that Europeans distinguish between cultural and civic aspects of their Europeanness with the former attached to "Europe" as a whole and the latter to the EU in particular. On the other hand, if the EU increasingly defines "Europe" in civic political terms, this would gradually become the dominant view of what it means to be European. This latter claim, if corroborated by further research, would lead to a quite dramatic conclusion regarding the impact of forty years of European integration on identity constructions in Europe, the guiding question of this volume. Not only would the EU increasingly define what it means to be 'European,' it would also fill 'Europeanness' with distinct post-national civic and liberal values as far as its substance is concerned. European integration would have led to a quite dramatic re-construction of European identity.

These optimistic conclusions have to be seen with a grain of salt, though. Mummendey and Waldzus, on the one hand, and Meinhof, on the other, see quite different dynamics at work which are not easily reconcilable with the liberal interpretation of what Europe means to its citizens.

\section{Europe's Multiple "Others” and the Ingroup Projection Model}

Social identities not only describe the content and the substance of what it means to be a member of a group. They also describe the boundaries of the group, i.e., who is 'in' and who is 'out' (see the introduction of this volume). As a result, we can infer quite a bit about the substance of European 
identity, if we know more about the European 'others.' The first problem we encounter in this context concerns Europe's "fuzzy boundaries." As Castano points out in his contribution, clear boundaries are an important ingredient of entitativity as a pre-condition of identification. But where does Europe end? A quick look at those international organizations that carry 'Europe' in their name shows that there is no uniform answer to the question. Europe is characterized by overlapping and unclear boundaries. The EU itself currently ends at the former East-West border of the Cold War, but will expand considerably toward the East and Southeast starting in 2004. At the EU Helsinki summit in December 1999, Turkey was given an accession perspective, too. The European Economic and Monetary Union with the single currency encompasses twelve of the fifteen EU member states. The European Single Market which includes the European Economic Area (EEA), encompasses some non-EU members such as Norway. 'Schengenland' with its absence of internal border controls, has even more complicated borders, since it includes Norway, but not the EU member Great Britain. Consider the following: If you travel by car from Germany via France and Spain to Portugal, you never have to show your passport and you retain one single currency, the Euro. However, if you travel by car and by boat from Germany via Denmak to Norway, you leave the Eurozone at the German-Danish border, the EU at the Danish-Norwegian border, but you never have to show your passport because of Schengenland. These are unclear boundaries par excellence.

Other European political organizations have even broader definitions of 'Europe.' The Council of Europe, for example, includes the Ukraine and Russia. The same is true in the security area for the Organization for Security and Cooperation in Europe (OSCE) which has the U.S. and Canada among its members. The OSCE 'Europe' ranges from San Francisco and Vancouver all the way to Vladivostok.

In sum, 'Europe' as a space of political organization and institutionalization has no clear boundaries. What about the social meanings and understandings of 'Europe?' There is surprisingly little in the various chapters on the constructions of the European "others." Meinhof's chapter strongly suggests that "othering" still takes place along the old Cold War border and that this includes the former border between East and West Germany. Her interviewees showed strong and hostile feelings against their fellow citizens in the immediate Eastern neighborhood. This was particularly significant among young people who had little personal experience with the Eastern 'foreigners,' thus corroborating findings from research about stereotyping according to which lack of contact increases negative stereotypes. In these interviews then, 'Europe' is still identified with 'Western' Europe, while the East continues to represent the European 'other.' 
Yet, one should not forget that strong 'othering' is context-dependent. As much as there is no fixed meaning what Europe constitutes positively, there are no fixed European 'others.' In the context of Meinhof's interviews which specifically examined border communities, it is not too surprising that the 'East' is represented as a threatening European 'other.' In a different social context, such as EU Committees on Employment and Social affairs (see Wodak's chapter), the U.S. and Japan are repeatedly referred to as the European 'out-group.' Here, the discourse centers around the European social model which is represented as distinct from both the American and Japanese systems of welfare states. In yet another political context, the German discourse on European integration, we found that Germany's own past of militarism and nationalism constituted the European 'other' against which the European integration project was to be built (Risse 2001;Risse and EngelmannMartin 2002; Engelmann-Martin 2002). In a similar way, the recent European-wide controversy about the ascent to power of a right-wing party in Austria constructed the "outgroup" as some sort of enemy within, since nobody denied that Austria was a legitimate member of the EU (Van de Steeg et al. 2003). The issue was whether European values of democracy and human rights were consistent with the rise to power of a xenophobic party which did not distance itself sufficiently from the European Nazi past. In sum, Europe has many 'others' which are referred to and represented in a context-dependent way. This does not mean at all that anything goes, but it warns us not to reify the concept of European identity and to fix its meaning once and for all (see also Siapera's chapter demonstrating that the meaning of Europe varies considerably depending on the discursive context).

Finally, Mummendey/Waldzus's ingroup projection model contradicts those who assume that the more citizens identify with Europe, the more they will be tolerant and sympathetic to fellow Europeans. The ingroup projection model suggests that this is highly conditional on the complexity with which Europe is presented. Citizens who project their own values on Europe and then identify with their 'national' Europe tend to be less tolerant with fellow Europeans. If, for example, German understandings of 'Europe' and the EU largely conform to visions of German social and political order, this might lower rather than increase German tolerance of Italians. The German discourse on the Euro and the convergence criteria was a case in point. Since the Euro was presented to a sceptical German public as the Deutsche Mark writ large, the Italian lira as the symbol of a weak currency was not supposed to join the Euro zone almost by definition. Of course, Germans were in for a surprise when Italy paid for Europe and qualified for EMU (see Sbragia 2001). 
At first glance, the evidence presented by Mummendey/Waldzus and Meinhof contradict the liberal cosmopolitan picture painted by Laffan's, Bruter's, and Citrin/Sides's chapters according to which identification with Europe increases tolerance for foreigners and decreases xenophobia. But Mummendey/Waldzus point out that the degree of ingroup projection depends on the complexity with which the superordinate identity (Europe in this case) is presented. A Europe that is simply Germany or France writ large, might invite ingroup projection, while a civic representation of Europe in the Habermasian sense would work against it. One possibility to solve the apparent contradiction would be to point out that the more Europe is identified in civic rather than cultural-ethnic terms (see chapters by Citrin/Sides and Bruter) and the more cultural diversity is emphasized (cf. Laffan's references to identity pointers in EU documents in her chapter), the less ingroup projection might play a role. We could also assume that the high correlation between income, education, and liberalism, on the one hand, and identification with Europe, on the other, might mitigate against ingroup projection (Citrin/Sides's chapter). In this case, however, it remains unclear whether it is European identity as such which works against ingroup projection, or the liberal and cosmopolitan values that higher educated people are more likely to hold. People holding liberal values might also be less xenophobic and, therefore, feel more European. These possibilities of how the various attitudes relate to each other and co-evolve suggest that it is far from clear which causal mechanisms are at work here and what accounts for what.

The somewhat contradictory findings lead to another issue, namely that European integration has been an elite-driven project so far and that, therefore, the identity changes toward a liberal civic identity are largely confined to the elite level.

\section{Elites, Masses, and the Psychological Existence of the European Union}

In general, the chapters confirm that the EU is an elite-driven project - similar to other nationbuilding projects. No wonder that identification with and support for Europe and its institutions is highest among political and social elites. Eurobarometer data demonstrate an enormous gap between elite support (in fact, elite consensus) for the EU, on the one hand, and widespread scepticism among the larger public, on the other. According to 1998 data, European elites supported EU membership almost unanimously (94\% mean across EU 15), while only a bit more than $50 \%$ of the mass public endorsed membership of their own country. Countries with the largest gaps between mass public and elite support for EU membership include Germany, Austria, Sweden, Belgium, Spain, 
Finland, and the United Kingdom (Spence 1998). Of course, these data do not measure identification with Europe, but support for the EU. But since attachment to Europe and support for integration co-vary, we can safely assume that identification with Europe among the elites is also higher than among the citizens where Europe and the EU run a distant second (or third after regional identification; cf. chapter by Citrin and Sides).

Yet, European and national identities are not zero-sum propositions and citizens can negotiate strong national identities and some secondary identification with Europe. Moreover, Citrin and Sides point to a quite dramatic change during the 1990s. From 1991 to 2000, the number of those who felt only attachment to their nation-state declined by almost twenty percent across the EU 15 , while the percentage of those who perceived some sense of belonging to their nation-state and to Europe increased by about the same number. The greatest increase in dual identification took place in Portugal and, interestingly enough, Germany, while Greece is the only outlier with no change at all. These developments are quite interesting, since support for EU membership and perceived benefits from EU membership - the latter being the main indicator for 'utilitarian' evaluations of the EU - declined during the 1990s (Citrin and Sides's chapter). At the same time, the correlations between identification with and attachment to Europe, on the one hand, and support levels for the EU as well as perceived benefits from EU membership, on the other hand, grew stronger.

How can we explain these developments, both the difference between elite and mass identification with Europe and the change during the 1990s? I suggest that the social psychological concept of entitativity is key (see Castano's chapter). Entitativity refers to the reification of a community resulting from increasingly shared cultural values, a perceived common fate, increased salience, and boundedness which then lead to collective identification. Castano points out, though, that increased salience of a community in people's lives does not necessarily increase support for the community; it could also result in growing rejection. Different levels of entitativity could well explain the enormous difference between elite and mass identification with Europe and the EU. The EU is certainly very real for Europe's political, economic, and social elites. Whoever is doing business in Europe has to constantly be aware of and refer to EU rules and regulations. Policy-makers and government officials on all levels of governance spend a considerable amount of their daily time dealing with the EU (Wessels 2000; Rometsch and Wessels 1996). In other words, the EU is has a real psychological existence for the European political, social, and economic elites as a result of which their sense of belonging is also rather high. 
For the citizens, the EU is still a more distant community than the nation-state, despite the fact that EU rules and regulations cover almost every political issue-area by now. There are at least three reasons for this relating to the concept of entitativity. First, while EU law is the law of the land, has direct effect, and overrides national law, EU authorities do not implement European rules and regulations, but national and subnational authorities do. Thus, when citizens are confronted with, say, environmental regulations in their daily lives, they do not even know that these are EU rules more often than not. The salience of the EU is rather low, even if the EU affects the citizens' lives on a daily basis. Second, 'Europe' has fuzzy boundaries. While there are plenty of indicators telling me that I have left Germany, it is unclear when I have left Europe. Having to show my passport is certainly not a valid indicator, as I argued above regarding the funny boundaries of Schengenland. The same holds for the Eurozone of the single currency which now encompasses 13 of the 15 EU member states.

Last not least, the elite discourses in most EU member states about the EU are ambivalent at best when it comes to 'shared values' and 'common fate.' On the one hand, there is the conscious identity construction of a liberal and civic community emanating from the EU and its various institutions (for the latest effort see Commission of the European Communities 2001; see also Laffan's chapter). On the other hand, national policy-makers routinely reify the nation-state in their dealings with Brussels. Whenever they can charge the EU for some tough decision at home, they adopt a populist rhetoric of conscious blame-shifting ("Brussels made me do it") and construct EU institutions as remote bureaucracies which cannot be trusted (in contrast to national governments, of course). At the same time, whenever the EU succeeds in solving a commonly perceived problem, national policy-makers take the credit in front of national media. Few citizens know, for example, that the liberalization of telecommunication markets slashing people's telephone bills across Europe during the last ten years, was actually due to EU initiatives. The ambivalent position taken by the media certainly does not help to increase the psychological existence of the European Union. As Siapera points out, journalists in Brussels who routinely report about the EU, hold multiple affiliations and see their professional role in ways which adds to the ambivalent and fuzzy picture of the EU emanating from the mass media.

In sum, it is probably safe to argue that the EU as a community still lacks quite some psychological existence as a condition for collective identification among the citizens. At the same time, things seem be changing, the more Europe hits home. The change in sense of attachment to Europe reported by Citrin and Sides could well result from an increasing reality of the EU in people's daily 
lives. The single market, Schengenland, for all their fuzziness, have enlarged the entitativity of the EU. The introduction of the Euro bills and coins has already left its mark on citizens' awareness of the EU. Eurobarometer data show that the Euro has quickly become the second most salient identity marker for the European Union (details in Risse 2003a). The advent of the Euro is a huge social science experiment. If Castano and others are right, we should observe an increase in identification with Europe in the years to come - with both the single currency and EU enlargement.

\section{The EU and Identity Change}

So far, I have mostly dealt with the chapters' findings concerning individuals' attachment to Europe in relation to their other collective identities. In social science jargon, I have discussed what we seem to know about the 'dependent variable' of this volume. Yet, the purpose of this book is not only to describe the degree to which citizens - elites and masses alike - identify with the EU and with Europe in general, but to explain identity change resulting from more than forty years of European integration. Do the European institutions affect collective identities? Do they lead to a greater sense of belonging to Europe? And if so, what are the mechanisms of identity change?

Unfortunately, our knowledge about the effects of the EU on collective identity only allows for tentative conclusions. There are two stories about identities and institutions, as mentioned in the introduction to this volume. The first - rationalist - story exogenizes identities and interests in the institution-building process. As a result, one would expect little impact of institutions on identities. In EU studies, the most prominent approach in this regard is liberal intergovernmentalism (e.g. Moravcsik 1998). Economic interdependence leads to changes in actors' preferences in favor of international cooperation. The preferences are aggregated by national governments who then negotiate binding agreements and institutions to insure credible commitments. This story leaves little space for institutional feedback effects on actors' preferences, let alone identities. We can treat it as the 'null hypothesis' for this book.

The second - constructivist - story endogenizes identities/interests and institutions. Accordingly and over time, institutions become part and parcel of the social and power structure that forms the social environment in which people act. Institutions tend to have constitutive effects on corporate actors such as national governments, interests groups, but also on individuals. Since people act in an environment structured by the institutions, the latter affect their interests, preferences, and collective 
identities. We should then expect identities and institutions to co-evolve with the causal arrows between the two pointing in both directions. The EU should be no exception. It might well have been created to serve specific interests based on given identities. But this would be the beginning, not the end of the story. Over time, we would expect a complex co-transformation of the EU together with people's identities and interests.

What do our authors tell us about these two stories? Once again, we need to distinguish between the level of political, economic, and social elites in Europe and that of ordinary citizens. The reason for this, once again, concerns the difference in psychological existence that the EU has for the two groups. As to the elites, various chapter in this volume demonstrate that the EU as an institution has had a clear impact on actors' collective identities. On the deepest, constitutive level, Laffan argues that the EU increasingly defines state identity in Europe. There are no 'neutral' states in Europe anymore vis-à-vis the EU. You are either in, almost in, or you are out. EU membership is a constitutive feature of statehood in Europe defining the social and institutional space in which nationstates act in Europe. As Sandholtz put it years ago, "membership matters" (Sandholtz 1996; see also Laffan, O'Donnell, and Smith 2000). In short, the EU increasingly is Europe.

This is a dramatic finding. If the EU defines what it means to be European, the European integration process has left its marks on the deepest levels of state- and nationhood in Europe. It has done so within only forty years and entirely peacefully. This disconfirms the notion that community- and nation-building is inherently linked to war-making (Tilly 1975, 1985). Forty years later, we can confirm what the founders of the European Community set out to do - to create a European peace order that redefines European statehood after centuries of wars and nationalism. Moreover, our findings substantiate empirically the Habermasian vision of a post-nationalist European identity and statehood (Habermas 1994, 1996). The chapters in this volume, particularly Laffan, Bruter, and Citrin/Sides demonstrate that Europeanness as "EUness" centers around a civic identity of liberal values such as human rights, democracy, market economy, and the welfare state.

Apart from these constitutive effects, European institutions also have a concrete impact on those working in and dealing with them. Laffan, Wodak, and Siapera demonstrate in their chapters how different types of institutions and different types of social (or discursive) contexts create different (role) identities relating to these institutions (see also Checkel forthcoming). The European Commission as the "guardian of the treaties" portrays an image and self-understanding of strong identification with Europe and European integration as the dominant role identity. In contrast, the 
Council of Ministers as well as the Committee of Permanent Representatives (Coreper) favors 'double hating' as the dominant role identity. Officials at Coreper need to be "janus-faced" (Lewis 1998b) in the sense of identifying with and representing their nation-state, but at the same time working toward a common European perspective for problem-solving. Last not least, the European Parliament (EP) as well as the working environment of journalists in Brussels create cross-cutting triple identities. EP members have to negotiate between their national identity, their Europeanness, and their party affiliation (see also Wodak's chapter), while journalists' professional identity interacts in various and context-dependent ways with their Europeanness and their national role identities (Siapera's chapter).

These chapters show that the different settings of EU institutions shape the role identities of actors involved in them in distinct ways. In contrast, the impact of the EU on identity changes among the European citizens is expected to be much more diffuse. We cannot assume that people differentiate clearly between, say, the European Commission and the European Parliament and that these institutions affect their daily lives in distinguishable ways leading to similar differences in ways of identification as was the case on the level of elites. But does this imply that we have to accept the null hypothesis that the EU has had no impact on the social identities of citizens?

Breakwell and Meinhof come closest to such a view. Breakwell emphasizes the emptiness of Europe as a category as a result of which it should play little or no role in shaping personal identities. But she also points out that the EU and its institutions should have a differential impact on nation-state identities. Meinhof found references to Europe and the EU only if the interviewer explicitly pointed people in this direction.

Bruter's chapter presents a methodology by which we could measure and specify the identityshaping impact of EU institutions better than the current survey instruments allow. His distinction between a civic and a cultural European identity allows to differentiate between identification with Europe in general, on the one hand, and the EU as a political institution, on the other. The evidence reported by Citrin and Sides is at least consistent with his interpretation. If Bruter's findings were generalizable across larger populations, we could conclude indeed that the EU has had its distinct 
identity-shaping and constitutive effects on both levels of elites and ordinary citizens. Yet, we need a lot more empirical research to make conclusive statements. ${ }^{2}$

Two factors appear to mitigate between EU institutions, on the one hand, and the identification with the EU among citizens, on the other. First and once again, the psychological existence of the EU should play a role (Castano's chapter). The more the social context in which people act is remote from or disaffected by the EU, the less people should identify with it in those contexts. The fuzzyness and unboundedness with which the EU is often presented in the national media discourses, is likely to matter here, too. While the experiments reported in Castano's chapter portrayed 'Europe' in overall positive terms as common fate, the media representation of the EU is much more ambivalent, if not outright negative in many instances. No wonder then that people with moderate levels of support for the EU have difficulty perceiving it as an entitative community. In sum, the variation in entitativity explains to a large extent the different levels of identification with the EU between the elites, on the one hand, and ordinary citizens, on the other.

Second, 'Europe' and European integration resonate in different ways with historically and culturally embedded understandings of the nation-state and of national sovereignty (Breakwell's chapter; see also Risse 2001). In the German and French political and intellectual discourses including the media, Europe has become part and parcel of what it means to be German or French these days. This is very different from the British discourse where a stark contrast has been constructed and is being reified between what it means to be 'English,' on the one hand, and 'European,' on the other. Here, Europe is still the - albeit friendly - 'other', i.e., the Continent (see Knopf 2002). One would assume that the EU's impact on collective identities varies significantly according to the degree to which Europe is embedded in the collective consciousness of citizens.

But what are the causal mechanisms by which the EU impacts on collective identities? The introduction by Herrmann and Brewer mentions three such mechanisms: Functional models assume that institutions almost automatically change people's perception of community and sense of belonging. Socialization concepts focus on actors' differential experiences with the institution and its consequences. Finally, persuasion models focus on institutions as identity-shaping agents. Deliberate efforts may be made to create collective identification through myths, symbols, or framing.

\footnotetext{
${ }^{2}$ Bruter is currently directing a Europe-wide research program in this area which is funded by the Commission's Fifth Framework Programme on Socio-Economic Research.
} 
What do our findings suggest about these mechanisms? There is little evidence for a functional logic at play. Haas's ideas that those elites that profit most from the union, would gradually transfer their loyalty to supranational institutions, seem to be disconfirmed (Haas 1958). Neofunctionalism's basic argument has been that European would lead to identity changes among those transnational interest groups benefiting from European integration. There is little evidence for such a mechanism. Farmers, for example, who arguably benefit most from the EU through the Common Agricultural Policy (CAP), are not particularly known for their enthusiasm for European integration. In more general terms, the data presented by Citrin and Sides (particularly table 3) show rather modest correlations between attachment to and identification with Europe, on the one hand, and individual perceptions of benefiting from the EU, even though this correlation grew stronger during the 1990s. The direction of the causal arrows also remains unclear from these data. One could, for example, turn the functional logic on its head and argue that strong identification with the EU leads to a sense of profiting from EU membership, rather than the other way round.

Socialization appears to be a better candidate for explaining the findings in various chapters. This is particularly true for those who are directly involved in the daily business of EU policy-making, either in Brussels or in national capitals (see chapters by Laffan, Wodak, and Siapera; see also Egeberg 1999; Lewis 2000; Wessels 2000; Checkel forthcoming). Laffan's chapter in particular demonstrates that individuals working in EU institutions tend to adjust to the various "logics of appropriate behavior" (March and Olsen 1998) in these institutions. These officials have direct experience with the institutions and need to internalize their rules of appropriatenes at least to some degree in order to be able to carry out their tasks. As a result, we expect them to develop a stronger sense of group identity with the EU than those who have less direct experience with its institutions.

Different degrees of socialization in terms of direct experience with the EU would also explain the huge gap between elite identification with Europe and the mass public where European identity runs a distinct second or third after national and/or regional identities. But the findings reported by Bruter and Citrin/Sides are at least consistent with an interpretation that sees socialization dynamics at work. The ability of citizens to identify with the EU in terms of a civic and political identity and the reported increase in (secondary) identification with Europe and EU during the 1990s could be explained on the basis of the socialization hypothesis. During that time period, the EU has become more visible in people's lives - from the single market to the single currency, 'Schengenland', Eastern enlargement, and most recently debates about institutional reform and the Constitutional 
Convention. At the same time, the EU has started portraying an image of itself as a political actor on the world scene going beyond pure market integration. The civic identity which Bruter finds in his data conforms precisely to the social construction which EU institutions try to convey to the citizens.

This leads to the third mechanism connecting institutions and social identities, persuasion. Persuasion does not constitute an alternative account to socialization, but complements it by emphasizing the active role of institutions as agents of identity construction. A complex picture emerges. On the one hand, the attempt by European leaders to deliberately construct the EU around civic and postnational values has made some inroads in people's perception of and identification with the EU. The growing visibility of the EU in people's lives is connected to a specific content and substance of European identity as civic and post-national emphasizing liberal values of democracy, human rights, and the social market economy with a strong welfare state component. On the other hand, as mentioned above, the EU is often presented in the national discourses including the media in a rather fuzzy and contradictory manner. In other words, the homogeneity which Castano calls for as a prerequisite for psychological existence and identity-building, is clearly lacking (see also Breakwell's chapter).

In sum, most chapters in this volume represent snapshots rather than long-term analyses of trends concerning European identity. As a result, we can only speculate about the mechanisms linking European institutions and identity change. The available evidence suggests, however, that further inquiry should probably pursue the investigation along the socialization and persuasion paths.

\section{Points of Contention and Methodological Implications}

The authors in this volume share a social constructivist understanding of social identities, irrespective of disciplinary backgrounds. Even primordial and essentialist constructions of national or ethnic identities are just this - social constructions (for a recent discussion see Fearon and Laitin 2000). There is also general agreement that social identities imply distinctions between 'in-groups' and 'out-groups,' entail cognitive, evaluative, motivational, and affective components, and are evoked in a context-dependent manner in situations when they become socially salient. It follows that individuals hold multiple identities as a result of which we can reject zero-sum understandings of national or regional versus European identities (see above). 
Yet, there are also points of theoretical contention represented in this volume resulting from different disciplinary, meta-theoretical, and methodological backgrounds of our authors. Two controversial issues need to be discussed here. First, how stable or fluid are social identities? On the one hand, data from mass opinion surveys (chapters by Bruter and Citrin/Sides) and from psychological experiments (chapters by Castano and Mummendey/Waldzus) imply a fundamental stability of identification processes. Otherwise, these data could not be used for descriptive and/or causal inferences on European identity. On the other hand, Meinhof and Siapera who use discourse analysis, emphasize the fluidity of social identities including European identity. In Siapera's case, for example, journalists' identification with Europe seems to vary from one discursive context to the next. Meinhof's data only revealed citizens' references to Europe when interviewers specifically pointed to it. She argues that peopole do not relate spontaneously to Europe and that they do so only when triggered by stimuli.

Does this imply that the identification processes found in mass survey data are statistical artefacts, at least on the level of ordinary citizens? Does it imply that the findings reported in this volume are methodology-driven in the sense that it depends on the method chosen whether we find European identity or not? I do not think so. One way to reconcile the different findings from survey data as compared to discourse analysis is to point to the context-dependency of social identities. If social identities including European identities are invoked in a context-dependent way whereever they become salient (and if only triggered by certain stimuli), they might appear rather fluid, but only at first glance. In fact, multiplicity, stability, and context-dependency of social identities can easily go together. Thus, what appears on the surface as fluid and forever malleable identities, might actually be pretty stable inside and "identity change" is simply a question of changing social contexts in which different layers of my multiple identities become salient. When my gender identity is invoked, my Europeanness might well recede in the background, and vice versa. Siapera's data, for example, are consistent with an interpretation that journalists identify with Europe to varying degrees and dependent on the social and political context in which this identification becomes salient or not. This is confirmed by Wodak's findings who also uses discourse analysis, but shows rather stable identity patterns between the groups investigated. Last not least, Meinhof's data with almost non-existing references to a common European fate might be explicable on the grounds that she studied border communities in which the overwhelming salience of the self/other distinction outweighs all other identification processes. 
A second issue of contention in this volume concerns the 'depth' of identification with Europe found in the various chapters. To what degree does identification with Europe imply loyalty to the EU defined as willingness to pay a price for one's identity? What happens when European policies and requirements conflict with national policies and traditions? There is little in the chapters of this volume enabling us to measure with some degree of certainty the potential costs attached to one's proclaimed identity. On the one hand, the findings of Laffan's and Wodak's chapters, for example, are consistent with a concept of role identities according to which actors know the rules of appropriateness attached to one's professional institution. These findings do not necessarily imply a deep sense of loyalty to the institution. On the other hand, the survey data reported in this volume try to figure out the degree to which people negotiate between their national/regional and their European identities. This implies people's sense of loyalty to their respective communities, at least to some extent (see Citrin and Sides on attachment to Europe).

Whether survey data succeed in tapping into people's loyalty toward the EU is an altogether different matter. We know little with regard to whether people who pretend to identify with Europe are also prepared to pay a price for their sense of belonging. This points to an important area of future research. ${ }^{3}$

\section{Instead of Conclusions: Why Bother? European Identity and the European Polity}

This volume concentrates, first, on describing the degree to which European elites and citizens identify with and feel attached to Europe and EU in its various dimensions and how this sense of European identity compares to other identifications which people might hold. Second, we try to explain the evolution of European identity and its variation among elites and citizens resulting from more than forty years of European integration and institutional buildup which leads to an increased salience and psychological existence of the EU in people's daily lives.

But why bother? At least political scientists are less inclined to study social identities per se, unless it can be shown that they matter somehow with regard to political outcomes. Does it make a difference to have demonstrated in this volume that elites and ordinary citizens alike increasingly identify

\footnotetext{
${ }^{3}$ A final point of contention concerns the apparent contradiction between the in-group projection model presented by Mummendey/Waldzus and the Eurobarometer data according to which identification with Europe correlates with tolerance for foreigners and immigrants and decreases xenophobia (chapter by Citrin and Sides). See above for a discussion.
} 
with Europe in conjunction with their sense of loyalty to national or subnational communities and that the EU increasingly defines and constitutes what it means to be European?

In general, political scientists and practicioners alike see a clear link between identity and a functioning political order. Accordingly, a democratic polity requires the diffuse support of the citizens in order to be legitimate. Identification with a political order is then seen as a source of diffuse support and, thus, of legitimacy. The higher the sense of loyalty toward a political community among the citizens, the more they are prepared to accept inconvenient decisions and policies of their governments, i.e. to pay a price for their identity. Europe as a polity should be no exception. Yet, conventional wisdom holds that the evolving European political order lacks a demos, mainly because there is neither European identity nor a European public sphere (Kielmansegg 1996; Scharpf 1999, 167). While this volume does not address the latter issue (but see Eder, Hellmann, and Trenz 1998; Eder and Kantner 2000; Kantner 2002; Van de Steeg et al. 2003), the chapters strongly challenge the notion that there is no significant European identity upon which to build a European polity.

The contributions demonstrate instead that there is an increasing sense of community among the European citizens, among elites and ordinary people alike. The EU clearly represents an entitative community for the political, economic, and social elites and it essentially constitutes modern statehood in Europe for them. Among the citizens, identification with and attachment to Europe (in conjunction with the nation-state) has also grown in recent years, while exclusive loyalties to the nation-state are in decline. The real cleavage in mass public opinion is between those who only identify with their nation, on the one hand, and those perceiving themselves as attached to both their nation and Europe, on the other hand (chapter by Citrin and Sides, see also Marks and Hooghe 2003). Moreover, the EU is understood as a civic community as distinct from cultural understandings of Europe in general.

To put it bluntly, this volume and other contributions to the state of the art of European identity show an emerging European demos. Yet, the European polity does not require a demos that replaces national by European identities, but one in which national and European identities co-exist. Europeanization, European integration, and European identities co-evolve over time, both at the elite and the mass levels. The causal arrows between European integration and institution-building, on the one hand, and the evolution of European identities, on the other, seem to run both ways. The increasing psychological existence ("entitativity") of the EU in people's daily lives seems to affect their identification with Europe as a political community. At the same time, support for European 
integration and attachment to Europe appear to be closely related motivating European elites toward continuing on the path of institution-building. A study on elite support for and opposition to the single currency revealed that the variation in national attitudes toward the Euro can be explained by differences in European identity among these elites (Risse et al. 1999; Risse 2003a; see also Banchoff 1999).

While the European polity seems to co-exist and co-evolve with a growing sense of European identity, overly optimistic statements should also be avoided on the basis of our findings. We still know little about the precise causal relationships and mechanisms between European integration, on the one hand, and European identity, on the other. This volume - and the ever-increasing literature on European identity in general - is much better at describing the degree to which people feel attached to Europe and the EU than at explaining the development of a European identity and linking it to the evolution of European institutions. The causal pathways identified here - institutionalization, socialization, persuasion - are far from specified. We can only hint at some of the reasons for the enormous variation in the sense of belonging to Europe revealed in our data. Finally, our findings suggest that European and national identities can go together and giving up one's loyalty to the nation is not required for a European demos. But we know little about those social and political contexts in which European and national identities might actually clash.

Despite these limitations, our volume demonstrates how much progress has been made in recent years in research on European identity and its relationship to other social identities which people hold. We show from a multi-disciplinary perspective that the sense of attachment to the EU among Europeans is continuously increasing leading to an emerging European demos as the democratic underpinning of the European polity. The available evidence shows that there is an increasing sense of community among the European citizens, among elites and ordinary people alike. The EU represents a genuine community of fate for the political, economic, and social elites in Europe and it essentially defines modern statehood in Europe for them. Among the citizens, identification with and attachment to Europe has also grown in recent years, while exclusive loyalties to the nation-state are in decline. The EU is understood as a civic community as distinct from cultural understandings of Europe in general. Given this state of affairs, the future of an enlarged European Union appears to look less gloomy than many observers seem to think. 


\section{References}

Anderson, Benedict. 1991. Imagined Communities. Reflections on the Origin and Spread of Nationalism. London: Verso.

Banchoff, Thomas. 1999. German Identity and European Integration. European Journal of International Relations 5 (3): 259-289.

Checkel, Jeffrey, ed. forthcoming. International Institutions and Socialization in Europe.

Commission of the European Communities. 2001. European Governance: A White Paper. Brussels: July 25.

Dewandre, N., and J. Lenoble, eds. 1994. Projekt Europa. Postnationale Identität: Grundlage für eine europäische Demokratie. Berlin.

Duchesne, Sophie, and Andre-Paul Frognier. 1995. Is There a European Identity? In Public Opinion and Internationalized Governance, edited by Oskar Niedermayer and Richard Sinnott. Oxford: Oxford University Press,

Eder, Klaus, Kai-Uwe Hellmann, and Hans-Jörg Trenz. 1998. Regieren in Europa jenseits öffentlicher Legitimation? Eine Untersuchung zur Rolle von politischer Öffentlichkeit in Europa. In Regieren in entgrenzten Räumen. PVS-Sonderheft, edited by Beate Kohler-Koch. Opladen: Westdeutscher Verlag,

Eder, Klaus, and Cathleen Kantner. 2000. Transnationale Resonanzstrukturen in Europa. Eine Kritik der Rede vom Öffentlichkeitsdefizit. In Die Europäisierung nationaler Gesellschaften. Sonderheft 40 der Kölner Zeitschrift für Soziologie und Sozialpsychologie, edited by Maurizio Bach. Wiesbaden: Westdeutscher Verlag, 306-331.

Egeberg, Morton. 1999. 'Transcending Intergovernmentalism.' Identity and Role Perceptions of National Officials in European Decision-Making. Journal of European Public Policy 6 (3): 456-474.

Eisenstadt, Shmuel N., and Bernhard Giesen. 1995. The Construction of Collective Identity. European Journal of Sociology 36: 72-102.

Engelmann-Martin, Daniela. 2002. Identity, Norms and German Foreign Policy: the Social Construction of Ostpolitik and European Monetary Union. PhD. dissertation, Department of Social and Political Sciences, European University Institute, Florence.

EOS Gallup Europe. 2001. Flash Eurobarometre 92 "Gouvernance". Report, Brussels: Janvier - Fevrier 2001.

Fearon, James D., and David D. Laitin. 2000. Violence and the Social Construction of Ethnic Identity. International Organization 54 (4): 845-877.

Haas, Ernst B. 1958. The Uniting of Europe: Political, Social, and Economic Forces 1950-57. Stanford, CA: Stanford University Press.

Habermas, Jürgen. 1994. Staatsbürgerschaft und nationale Identität. In Projekt Europa. Postnationale Identität: Grundlage für eine europäische Demokratie, edited by N. Dewandre and J. Lenoble. Berlin,

---. 1996. Der europäische Nationalstaat - Zu Vergangenheit und Zukunft von Souveränität und Staatsbürgerschaft. In Die Einbeziehung des Anderen, edited by Jürgen Habermas. Frankfurt/Main: Suhrkamp,

Kantner, Cathleen. 2002. Transnationale Öffentlichkeit und die Demokratiefähigkeit der Europäischen Union. PhD. Dissertation, Philosophische Fakultät III, Humboldt-Universität, Berlin.

Kielmansegg, Peter Graf. 1996. Integration und Demokratie. In Europäische Integration, edited by Markus Jachtenfuchs and Beate Kohler-Koch. Opladen: Leske \& Budrich, 47-71.

Knopf, Hans Joachim. 2002. Britain and European Integration Between 1950 and 1993: Towards a European Identity? $\mathrm{PhD}$. dissertation, Department of Social and Political Sciences, European University Institute, Florence.

Laffan, Brigid, Rory O'Donnell, and Michael Smith. 2000. Europe's Experimental Union. Rethinking Integration. London: Routledge.

Lewis, Jeffrey. 1998a. Constructing Interests: The Committee of Permanent Representatives and Decision-Making in the European Union. PhD. dissertation, Department of Political Science, University of Wisconsin-Madison, Madison WI.

---. 1998b. Wearing a Janus-Face: The Permanent Representatives of the European Union. Paper presented at Eleventh International Conference of Europeanists, at Baltimore MD.

---. 2000. The Method of Community in EU Decision-Making and Administrative Rivalry in the Council's Infrastructure. Journal of European Public Policy 7 (2): 261-289.

March, James G., and Johan P. Olsen. 1998. The Institutional Dynamics of International Political Orders. International Organization 52 (4): 943-969.

Marcussen, Martin, Thomas Risse, Daniela Engelmann-Martin, Hans-Joachim Knopf, and Klaus Roscher. 1999. Constructing Europe. The Evolution of French, British, and German Nation-State Identities. Journal of European Public Policy 6 (4): 614-633.

Marks, Gary, and Liesbet Hooghe. 2003. National Identity And Support for European Integration. manuscript. Berlin Chapel Hill.

Martinotti, Guido, and Sonia Steffanizzi. 1995. Europeans and the Nation-State. In Public Opinion and Internationalized Governance, edited by Oskar Niedermayer and Richard Sinnott. Oxford: Oxford University Press, 163189.

Moravcsik, Andrew. 1998. The Choice for Europe: Social Purpose and State Power From Rome to Maastricht. Ithaca NY: Cornell University Press. 
OPTEM. 2001. Perceptions de l'Union Europeenne. Attitudes et attentes a son egard. Etude qualitative aupres du public des 15 Etats membres et de 9 pays candidats a l'adhesion. Versailles: Commission Europeenne, Mars 2001.

Risse, Thomas. 2001. A European Identity? Europeanization and the Evolution of Nation-State Identities. In Transforming Europe. Europeanization and Domestic Change, edited by Maria Green Cowles, James A. Caporaso and Thomas Risse. Ithaca, NY: Cornell University Press, 198-216.

---. 2003a. The Euro between national and European identity. Journal of European Public Policy 10 (4): 487-503.

---. 2003b. Toward a European Public Sphere? Theoretical Considerations. Paper presented at European Union Studies Association, March 26-30, at Nashville TN.

Risse, Thomas, and Daniela Engelmann-Martin. 2002. Identity Politics and European Integration: The Case of Germany. In The Idea of Europe. From Antiquity to the European Union, edited by Anthony Pagden. Cambridge: Cambridge University Press, 287-316.

Risse, Thomas, Daniela Engelmann-Martin, Hans Joachim Knopf, and Klaus Roscher. 1999. To Euro or Not to Euro. The EMU and Identity Politics in the European Union. European Journal of International Relations 5 (2): 147187.

Rometsch, Dietrich, and Wolfgang Wessels, eds. 1996. The European Union and the Member States: Towards Institutional Fusion? Manchester and New York: Manchester University Press.

Sandholtz, Wayne. 1996. Membership Matters: Limits of the Functional Approach to European Institutions. Journal of Common Market Studies 34 (3): 403-429.

Sbragia, Alberta. 2001. Italy Pays for Europe: Political Leadership, Political Choice, and Institutional Adaptation. In Transforming Europe. Europeanization and Domestic Change, edited by Maria Green Cowles, James A. Caporaso and Thomas Risse. Ithaca, NY: Cornell University Press, 79-98.

Scharpf, Fritz W. 1999. Regieren in Europa. Frankfurt/M.: Campus.

Spence, Jacqueline M. 1998. The European Union. "A View from the Top" - Top Decision Makers and the European Union. Report, Wavre: EOS Gallup Europe,

Tilly, Charles. 1975. The Formation of the Nation State. Princeton, NJ: Princeton University Press.

---. 1985. War Making and State Making as Organized Crime. In Bringing the State Back In, edited by Peter B. Evans, Dietrich Rueschemeyer and Theda Skocpol. Cambridge: Cambridge University Press,

Van de Steeg, Marianne, Valentin Rauer, Sylvain Rivet, and Thomas Risse. 2003. The EU as a Political Community. A Media Analysis of the 'Haider Debate' in the European Union. Paper presented at EUSA Biannual International Conference, March 27-30, at Nashville TN.

Wessels, Wolfgang. 2000. Die Öffnung des Staates. Modelle und Wirklichkeit grenzüberschreitender Verwaltungspraxis 1960-1995. Opladen: Leske \& Budrich. 